\title{
Comparative evaluation of screening and supplementary assays used in HCV diagnosis
}

\author{
Vidya Nerurkar*, Prabhupad Rath, Rashmi Khadapkar, Simi Bhatia, Bibhu Ranjan Das \\ From First International Science Symposium on HIV and Infectious Diseases (HIV SCIENCE 2012) \\ Chennai, India. 20-22 January 2012
}

\section{Background}

Evaluation of serological assays for hepatitis C (HCV) antibody screening is crucial, as supplemental testing [Nucleic Acid Testing \& Recombinant Immunoblot Assay (RIBA)] to verify anti-HCV reactive results is not widely practiced, due to limited availability and high cost. The current study was undertaken from January to May 2011, to evaluate 4 serological assays for HCV diagnosis, viz-a-viz HCV RNA PCR and RIBA.

\section{Methods}

87 patient specimens were screened for anti-HCV, using COBASe411(eCLIA, Roche, Germany), Axsym (MEIA, Abbott, Germany), HCV Qualisa (ELISA, Qualpro, India) and HCV Tridot (Rapid Immunofiltration, J. Mitra, India), and for presence of HCV RNA using COBAS TAQMAN 48 analyzer (Roche). Specimens with discrepant results were referred internationally for RIBA.

\section{Results}

58/87 (66.7\%) specimens were anti-HCV reactive. 37/58 were HCV RNA PCR positive, indicating active HCV infection. Sensitivities of COBAS, Axsym, Qualisa and Tridot were $100 \%, 97.3 \%, 72.9 \%$ and $75.7 \%$ respectively. False negative anti-HCV results, obtained by Qualisa and Tridot, were seen in 10 and 9 patients respectively and could be attributed to the synthetic peptide coating in these kits. 6 of these patients were chronic renal failure cases, on hemodialysis. All kits showed specificity of $100 \%$. False positivity was not observed, possibly because our study group comprised of patients with suspected HCV infection.

\section{Conclusion}

Anti-HCV assays on COBASe411 (eCLIA) and Axsym (MEIA) platforms appear reliable. The study thus

\footnotetext{
* Correspondence: vidya.nerurkar@srl.in

Super Religare Laboratories, Mumbai - 400 062, Maharashtra, India
}

highlights the importance of using recombinant antigen based tests for anti-HCV screening. A strong need to conduct larger studies for performance evaluation of anti-HCV tests in specific patient subpopulations is felt.

Published: 4 May 2012

doi:10.1186/1471-2334-12-S1-P65

Cite this article as: Nerurkar et al.: Comparative evaluation of screening and supplementary assays used in HCV diagnosis. BMC Infectious Diseases 2012 12(Suppl 1):P65.
Submit your next manuscript to BioMed Central and take full advantage of:

- Convenient online submission

- Thorough peer review

- No space constraints or color figure charges

- Immediate publication on acceptance

- Inclusion in PubMed, CAS, Scopus and Google Scholar

- Research which is freely available for redistribution
C Biomed Central

\section{() Biomed Central}

(C) 2012 Nerurkar et al; licensee BioMed Central Ltd. This is an Open Access article distributed under the terms of the Creative Commons Attribution License (http://creativecommons.org/licenses/by/2.0), which permits unrestricted use, distribution, and reproduction in any medium, provided the original work is properly cited. 